\title{
THE LA TÈNE GRAVE AND OTHER EVIDENCE OF LTB-D1 SETTLEMENT IN MIKULOVICE, PARDUBICE DISTRICT
}

\author{
TEREZA JOŠKOVÁ ${ }^{0}$ - VÍT VOKOLEK - PAVEL SA N KO T ${ }^{1}$
}

\begin{abstract}
The paper presents a comprehensive evaluation of the still largely unattended activities from the La Tène period at the major polycultural site in Mikulovice, Pardubice distr., Czech Republic. The site is known mainly for rich finds of grave gifts from the Early Bronze Age and also for its extensive settlement activities in HA2-LTA. Thanks to the rescue excavations prior to the construction of residential houses in recent decades, the situation and artefacts of the course of LTB-D1 have been captured. The main axis of the paper is the analysis and evaluation of the find of the solitary La Tène inhumation grave. On this basis, it addresses the issues of possible links and contacts between the eastern Bohemian region and the Moravian area. The topic of settlement activities in Mikulovice during the younger period of the Iron Age is further addressed by analysing the pottery and evaluating several captured residential situations.
\end{abstract}

Keywords: Eastern Bohemia, La Tène civilisation, settlement, isolated grave.

\section{INTRODUCTION}

The polycultural site Mikulovice, Pardubice district, has been an object of archaeological interest since the $19^{\text {th }} \mathrm{c}$. (most recently in Hlava/Frolik 2020), and it is famous especially for its exceptional finds from the Early Bronze Age (collectively in Ernéel Langová 2020) and from the late Hallstatt period to the early times of La Tène (Jošková 2020; Sedláček/ Sankot 2013). However, an unexpected discovery of an inhumation grave in 2009 indicated unforeseen activities during the La Tène period itself. Owing to the recent rescue excavation, other small residential situations and finds have been captured; they can be dated to LTB-D1 stages (Fig. 1). Although these finds are unique so far, in relation to the previous development from HD-LTA, by their nature they help significantly in the research of the La Tène activities in the Pardubice region. The following paper aims to evaluate and bring into the overall context all activities from the La Tène period in Mikulovice.

\section{THE NATURE OF THE SITE AND THE CIRCUMSTANCES OF THE EXCAVATIONS}

Mikulovice is situated on a gravel river terrace of the Chrudimka river, which is covered by loess drifts or gravel sand (Demek/Mackovčin 2006). The altitude ranges most frequently from 240 to $252 \mathrm{~m}$ a.s.l., with a significant strategic landmark in the form of the Mikulovice hill, $275.2 \mathrm{~m}$ a.s.l. The area is part of a fairly fertile area of the eastern Elbe basin and from a geomorphological point of view it belongs to the Heřmanoměstská tabule (Heřmanův Městec Shield; Jančák/Hrnčiarová/Mackovčin 2009, 66, 67, 122-125).

A detailed overview of the existing archaeological activities on the site is described in a recently issued publication (Hlava/Frolik 2020, 24-32), along with a list of all of its cultural components from the Neolithic to the beginning of the Migration Period (Jošková/LangoválJílek 2020). The paper presents the latest findings from the excavations (Frolik/Sedláček/ Švédová 2010; Sedláček 2007; Sedláček et al. 2009; Sedláček/Švédová 2011; Zavoral 2015 and further literature) conducted by the East Bohemian Museum in Pardubice since 2006. ${ }^{2}$

\section{THE DISCOVERY OF THE INHUMATION GRAVE}

An isolated inhumation grave, marked as feature 2094, was examined on parcel no. 241/62, in the location called ' $V$ loučkách' at the end of June and in early July 2009 (Frolík/Sedláček/Švédová 2010, 13).

\footnotetext{
1 The participation of P. Sankot was financially supported by Ministry of Culture of the Czech Republic (DRKVO 2019-2023/17.II.c, National Museum, 00023272).

2 The Institute of Archaeology of the Czech Academy of Sciences in Prague also significantly contributed to the research during the period 2006 -2010; regional museums in Vysoké Mýto and Chrudim were also participating.
} 


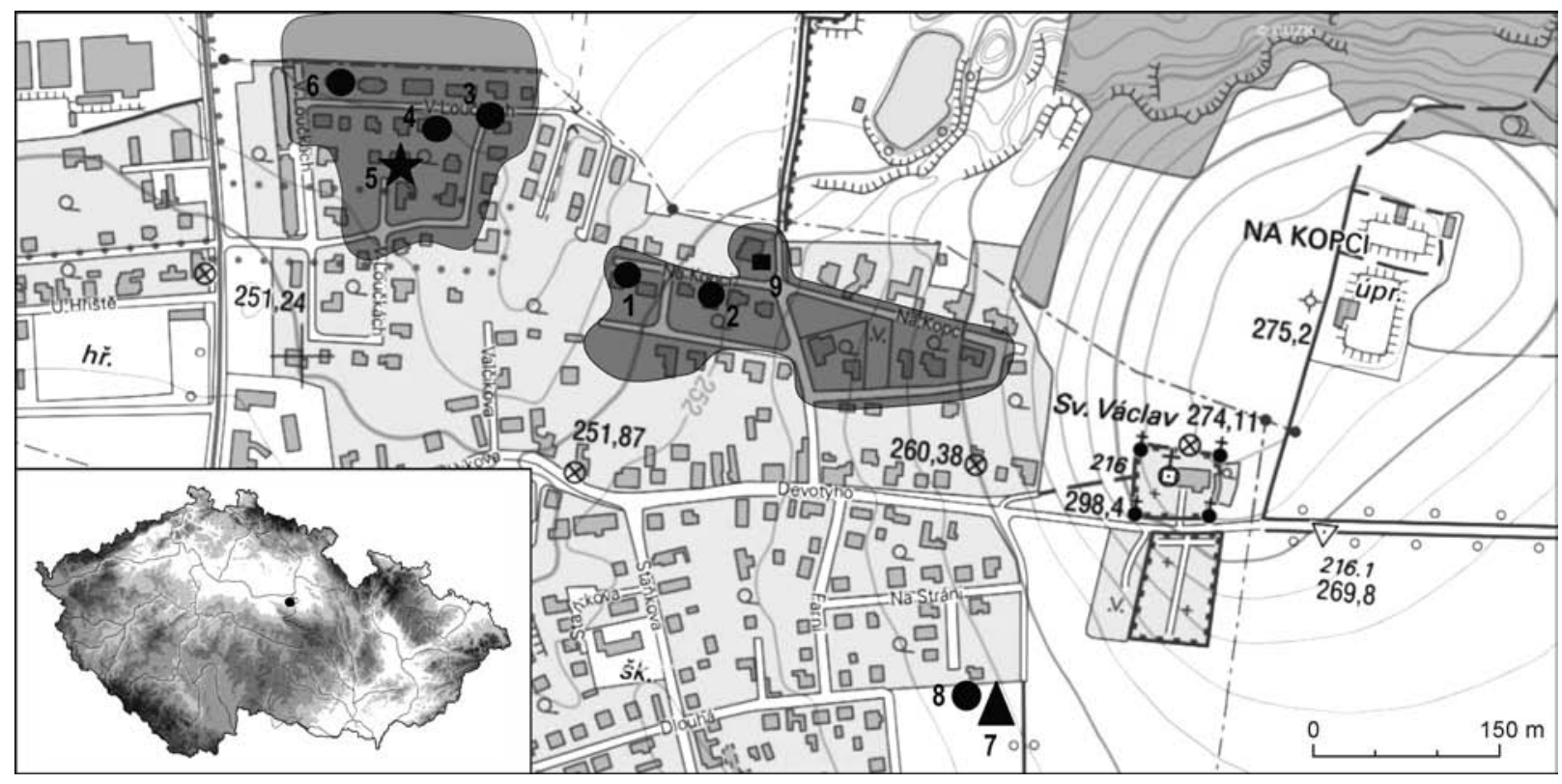

Fig. 1. Mikulovice, Pardubice distr. Site plan with marked La Tène activities. 1-4, 6-8 - small settlement finds; 5 - inhumation grave; 7 - sunken hut; 8 - early La Tène mask brooch. Legend: black - finds from the period LTB-D1; dark grey polygons - the extent of settlement in HD2-LTA (compiled by T. Jošková).

\section{The finding situation}

After cleaning, the top of the grave appeared to be an irregular rectangle with partially rounded angles, sized $287 \times 134 \mathrm{~cm}$, with its longer axis oriented in the NNE-SSW direction. At a depth of $20 \mathrm{~cm}$, the grey-brown filling of the feature narrowed down to a rectangular space with maximum dimensions of $210 \times 60 \mathrm{~cm}$. The grey-brown clay filling, mixed with loess, reached the rounded bottom in the form of a step recess at a depth of $46 \mathrm{~cm}$. The field plan also documents the traces of a wooden coffin. The buried individual's skeleton was in a normal, stretched supine position, with the head-to-north-north-east orientation with azimuth of 23 degrees (Fig. 2). The palm of the left hand was under the pelvis, with the palm of the right hand placed on the pelvis. The grave goods included an iron fibula, placed on the middle part of the chest, a bronze bracelet on the left hand and an iron ring left of the pelvis (Jošková 2020, 134, 135, fig. 55). The indication of an alleged find of an iron rivet beside the skull in the field plan of the grave could not be verified.

\section{Evaluation of finds}

The bronze bracelet with a rounded D-shaped cross-section $8 \times 4 \mathrm{~mm}$ in size has an internal diameter of $60 \mathrm{~mm}$ (Fig. 2: 2). The bracelet has a smooth surface. Viewed from the side, its ends are thickened in a clubshaped form; viewed from the top, they are thickened in a seal-shaped form. The smooth-faced bronze bracelets, with differently thickened profiles, form a numerous series in the find pool from flat cemeteries already since the LTB1b-c stage (Čižmár̆ 1978, 137; Holodňák 1988, 93, fig. 25; Sedláčková/Waldhauser 1987, fig. 41). Bronze rings with seal-shaped thickened ends, separated from the body by a knob, may be found in some substantially younger finds units, even from the period of LTB2b (Mangel/Zavoral 2017, 326). The shape of the Mikulovice bracelet corresponds to the display of the BR-A4-A type, classified by J. Bujna (2005, 17, fig. 3), in the typology of ring jewellery from flat cemeteries from Slovakia, representing an advanced form from the transition of the LTB1/LTB2 stages.

The younger dating is indicated by the shape of the iron fibula in the Mikulovice grave furnishing (Fig. 2: 1a). The iron fibula has a foot equipped with a massive knob, $18 \mathrm{~mm}$ in diameter, with an end leaning towards the bow with a half cuff. A part of the bow, preserved only at the winding, indicates the start of probably a high arched shape with an oval section. The extended winding has of $4+4$ threads with a large diameter of $16 \mathrm{~mm}$, the string is missing. Based on the X-ray image (Fig. 2: 1b), captured by J. Hošek, ${ }^{3}$ the entire winding is filled

\footnotetext{
3 Data for X-ray computed tomography (CT) was performed using a universal X-ray system X-Test (provided with a $200 \mu \mathrm{m}$ resolution detector) employing a primary X-ray generator (COMET MXR-225HP/11 set at max. voltage $225 \mathrm{kV}$, max. power $800 \mathrm{~W}$ and $0.4 \mathrm{~mm}$ focal spot).
} 


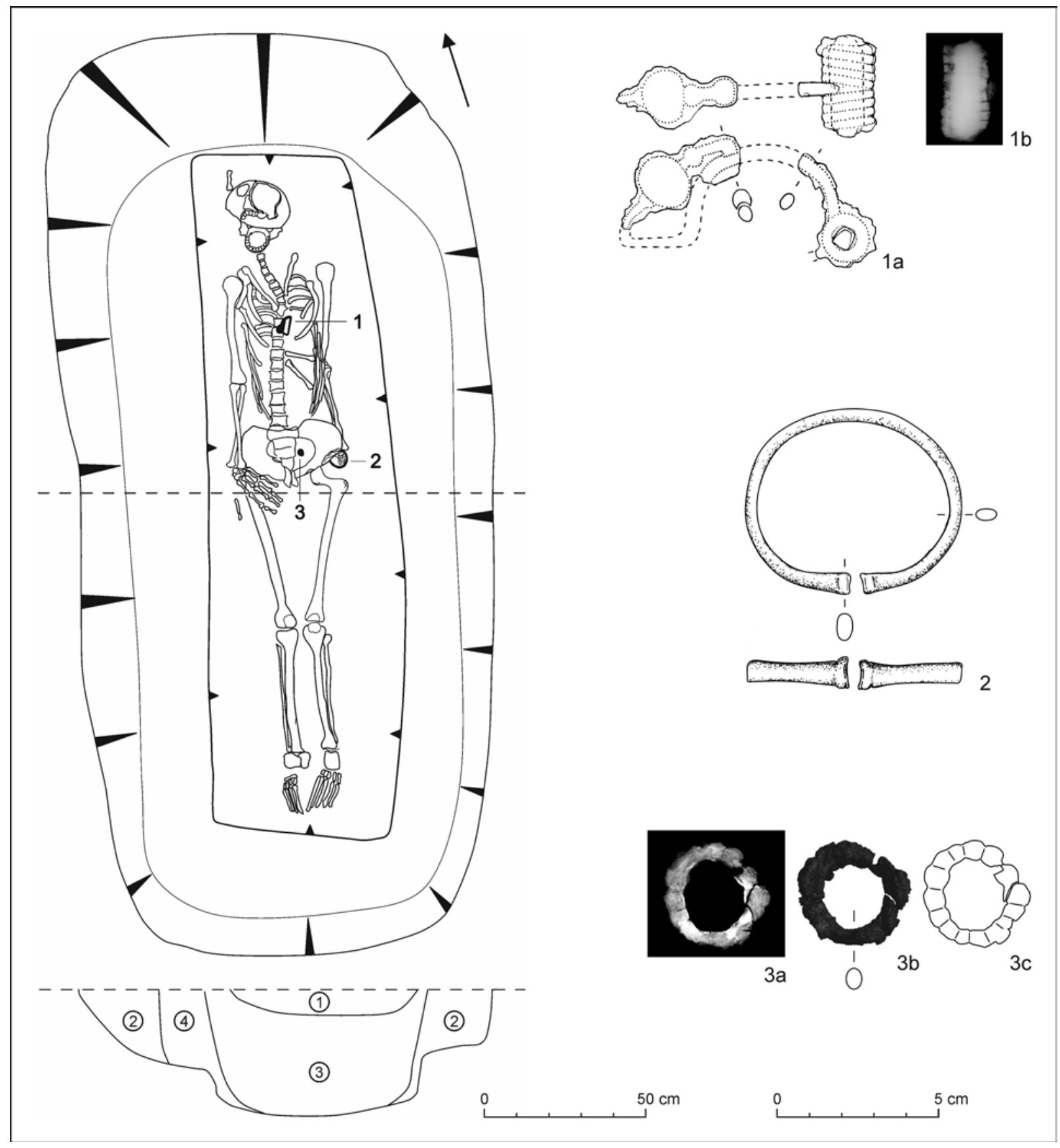

Fig. 2. Mikulovice, Pardubice distr. La Tène inhumation grave (feature 2094) with equipment. 1 - iron fibula (b - X-ray image of its winding); 2 - bronze bracelet; 3 -iron ring ( $\mathrm{a}$ - X-ray image, $\mathrm{b}$ - today surface, $\mathrm{c}$-interpretation). The layers of the grave profile correspond to the description in the text (drawing 1a - M. Černý; 2, 3c-T. Jošková; digitization T. Jošková; X-ray images by I. Nacherová and J. Hošek).

with a massive iron axis, $10 \mathrm{~mm}$ in diameter, with tapered ends. The assumed length of the fibula should be $72 \mathrm{~mm}$. In the detailed typology of iron fibulas from Slovakia, it corresponds to the EF-C9A shape, which represents the leading type of the groups 6, 7 (Bujna 2003, 72, fig. 47A). Chronologi- cally, group 6 belongs to the LTB2b stage (Bujna 2003, 99).

The iron ring has an external diameter of $34 \times 31 \mathrm{~mm}$. X-ray images (Fig. 2: 3) captured by I. Nacherová display details of its shape, made of knobs, each $6.4 \mathrm{~mm}$ in diameter. ${ }^{4}$ The range of

\footnotetext{
4 In the conservation laboratory of the Central Bohemian Museum in Roztoky, Prague, using the Eresco 42 industrial X-ray unit at $90 \mathrm{kV}, 2 \mathrm{~mA}$ and $100 \mathrm{kV}, 1.5 \mathrm{~mA}$.
} 
analogous shapes of rings with a knobs body can be observed in the find pool from La Tène cemeteries from the Moravian area. J. Čižmářová (2009, 79, pl. 30: 7) shows an iron ring with a knobs structured surface, $35 \mathrm{~mm}$ in diameter, from the cemetery in Holubice - 'Dílce', Vyškov distr. Another one comes from the LTB2a stage grave in Mostkovice 1, 'Za hřbitovem' site (Čižmářová 2017, 178, pl. 62: 11). Yet another $27 \times 24 \mathrm{~mm}$ diameter bronze ring with knobs along its perimeter can be found in a richly equipped female grave $\mathrm{K} 800$ on the cemetery in Hrušky, Vyškov distr. (Čižmářová 2013, 127, pl. 20: 13). It is probably not accidental that an iron ring with a $30 \mathrm{~mm}$ diameter, with knobs along the perimeter was also identified in Bohemia among the more recent finds of the grave goods from the grave 122/2010, cemetery in Bašt', Praha-východ district, along with weapons and iron fibulas from the end of the LTB2 stage, known from the Danube basin area (Pecinouská/Baloun/Sankot 2014, 753, 759, fig. 6: B: 3).

From the point of view of social interpretation, the grave from Mikulovice, equipped with one bronze bracelet, can be assigned to garniture 400, as defined by J. Waldhauser (1987, 39, fig. 5), which is associated with the burials of young to adult women. In the case of graves equipped with a single bronze bracelet, which, in the 410 garniture variant, contains one or two fibulas as well as one or more objects in addition to one bracelet, which is also the case of the Mikulovice grave, the original definition of this garniture by J. Waldhauser (1978 II, 152, pl. 58; 1979, 56, pl. 4) allows also the possibility of being identified as the equipment of a male grave. This is also in line with the conclusion of the anthropological assessment of the grave of Mikulovice, which identifies the buried individual as a man of the adultus I-II age group, within the range of 25-40 years of age (Stránská 2016).

\section{Assessment of the location and layout of the grave}

In the middle section of the grave filling profile, there is a more or less horizontal layer 1 (deep black clay fill $)^{5}$ stretching from the level of the overburden to the depth of about $10 \mathrm{~cm}$. Layer 1 covers the greybrown clay layer 3 , which fills the grave pit as far as the curved bottom of the grave. At the interpretation level, this form of the profile appears to reflect a $58 \mathrm{~cm}$ wide wooden coffin with a rounded bottom, gouged from a tree trunk(?) and covered with a plate on the top. A similar image of the profile of a wooden coffin, with a similar width of $50-55 \mathrm{~cm}$, with a rounded bottom, gouged from a tree trunk and covered from the top with a horizontal plate, is known from the grave 18 from the burial grounds in Blučina, Brno-venkov district (Čižmářová 2011, 105, pl. 14: 3). The eastern Bohemian example of the use of a wooden sarcophagus with a rounded bottom, which was gouged from a tree trunk, including an observable part of the originally undoubtedly horizontal sarcophagus lid, is the find of the grave in Chrudim (Mangel/DanielisoválJílek 2013, fig. 32: 1; Musil 2008, 50, fig. 4).

Similar to the profile of the pit of grave 12 from Radovesice I (Waldhauser 1987, fig. 7), the profile of the Mikulovice grave pit also clearly shows another coloured layer 4, attached from the western side to the contour of the sarcophagus. It cannot be excluded that this may be a result of the lateral sealing. According to J. Waldhauser $(1987,51)$, the use of wooden sarcophagi can be observed throughout the Bohemian-Moravian-Silesian area, taking into account the quality of recent research, in particular. On the recently examined burial grounds in Vliněves, Mělník district, the layout of graves with a wooden coffin or another structure was identified in graves with all types of grave equipements (Limburský et al. 2015, 227, tab. 2).

Even with recent excavation of Bohemian La Tène cemeteries, the layout of the grave pit with a perimeter step, running around the central part of the Mikulovice grave pit, remains unique. This circumferential step is $25-45 \mathrm{~cm}$ wide here. On the other hand, various forms of this grave architecture, with different grave pit layouts from the standard shape, can be found in the La Tène cemeteries on the territory of Moravia, again mostly with the evidence of a wooden coffin. We can mention the shape of the grave 20 on the cemetery in Blučina 3 - 'Konopné zahrádky', Brno-venkov district (Čižmářová 2011, 106, pl. 15: 2). Similarly, it is found in the grave on the cemetery in Žatčany, Brno-venkov district (Čižmářová 2011, pl. 20: 3), furthermore grave 13 on the cemetery in Lovčičky 1 - 'Strážce', Vyškov district (Čižmářová 2013, pl. 70: 2) or graves 41 and 51 on the cemetery in Hulín - ‘U Isidorka', Kroměříž district (Čižmářová 2017, pl. 85: 2; 86: 2).

The documentation of the cemetery in Hustopeče 2 - 'Šibenky', Břeclav district (Čižmářová 2019, 139-159, pl. 45-56), presents a whole range of layouts of the bottom of the grave, where almost half of the burials is recorded in the eccentric position, which created space for a wide circumferential step or free area. The finding situation of the grave

\footnotetext{
5 Layer 2 was mix clay with loess (grave backfill).
} 
K 813 at Hustopeče 2 - 'Šibenky' and K 571 at the Pavlov 2 - 'Horní pole I' cemetery provides an explanation of the possible function of these peripheral steps to locate part of the grave goods (Čižmářová 2019, 280, pl. 59: 2) or offerings (Čižmářová 2019, 144, pl. 46: 5).

The skeleton in the Mikulovice grave was oriented with its head toward the north-north-east. In addition to some regions of Switzerland and Bavaria, the orientation of the skeleton with its head toward the north is typically dominant in Bohemia and the neighbouring Moravia and Silesia regions (Lorenz 1978, 71). The north-south to northeast-southwest direction of the grave axis is also most frequent in the nearest area of the La Tène cemeteries in the upper Elbe basin area (Mangel 2009, 31).

In addition to the chronological classification, the grave from Mikulovice raises, in particular, the question of its isolated position on the site (Fig. 1: 5). Due to the fact that the La Tène cemeteries were established near the existing settlements also in the eastern Bohemian region (Mangel 2009, 44-49), the entirely isolated placement of the grave in Mikulovice in the whole surveyed area is another prominent property of this feature. The conducted advance surveys confirm the absence of other graves in the entire surrounding area of more than $14,700 \mathrm{~m}^{2}$ (with a wider area up to $42,000 \mathrm{~m}^{2}$ ). The completely intact condition of feature 2094 helps eliminate the possibility of any traces of deliberate destruction rites of graves. There is a possible link with the $35 \mathrm{~m}$ distant feature 1942/2009 of a storage pit on parcel 241/56 (Fig. 1: 4), defined as part of the settlement component with a theoretical possibility of similar dating as the above studied grave. Alternatively, there were other small pottery finds on the site that can be dated to LTB-C1 (Fig. 1), which are addressed below.

Professional reasons cannot be excluded, either in accordance with the example of the 'Sklárské údolí' location near Prášily, Klatovy district (Dreslerová et al. 2019), with an isolated position of separate settlement units with an extremely low degree of identification by contemporary archaeological methods. Another possibility of deliberately isolated placement of the grave with the burial of a socially sanctioned individual cannot be excluded. Such a practice has been recently identified, for example, in an isolated group of graves at the cemetery in Hostivice, Praha-západ district; the graves are located several dozen meters from the standard cemetery. This isolated group of graves includes burials of individuals with a possible physical handicap, as well as individuals of exogenous nature, including an inhumation grave of a man aged $35-50$ with a stone lining of the grave pit, equipped only with a collection of pottery typical for the Moravian region (KlementoválSankot 2020, 247, 248, fig. 2; 3: 2; 6: 1, 2).

\section{The Mikulovice grave in time and space}

In addition to the analogies of the metal belt ring equipment, the relationship between the grave in Mikulovice and in some flat cemeteries in the Moravian region in the form of a grave pit with a significant peripheral step was discussed. This corresponds to the Moravian analogies and it is probably also associated with the ritual practices of one certain community representing the La Tène culture. In the Chrudim-Pardubice region, the relationship between the La Tène civilization representatives and the areas lying east of Bohemia is also marked by the oldest flat grave in Chrudim, with the element of the funeral rite typical specifically of the areas east of Bohemia, starting with Moravia. Namely, it is the presence of a bone of a lower extremity of a swine, identified among the bone finds from the respective grave (Musil 2008, 52).

According to the conclusions of $J$. Waldhauser $(1988,65,66)$, the regions in the western part of eastern Bohemia, in the Mrlina and upper Cidlina river basins 'tended more toward central Bohemia'. According to this author (Waldhauser 1988, 65), the onset of the phenomenon of the La Tène flat cemeteries in the mentioned region can be dated already to LTB1b, whereas the La Tène settlement with flat cemeteries in the eastern upper Elbe basin area, according to T. Mangel $(2009,39)$, can be questionably dated to the end of the LTB1b-c stage, and with certainty from the LTB2a stage. On the other hand, the southern situated concentration of La Tène cemeteries in the Chrudim area, subsequently extending to the Pardubice area, starts already in the LTB1b-c (Mangel/Zavoral 2017, 327).

Due to the geographical location of the ChrudimPardubice region, the cultural influence of the Moravian region is not surprising. Contacts between the eastern Bohemian and Moravian regions in the La Tène period were already recognized by J. Waldhauser $(1988,67)$ and V. Vokolek $(1993,79)$; the links of some of the eastern Bohemian finds were traced in this direction, as far as the Carpathian Ba$\sin$ (Sankot 1991). These contacts are also illustrated by the map of spreading of ritual manifestations, deposition of pottery, presence of animal bones and scissors, typical of the funeral rite in the areas of the Carpathian Basin, Moravia and Silesia, with the subsequent expansion to the La Tène flat cemeteries, particularly in the area of eastern Bohemia (Waldhauser 1987, fig. 9). The work of T. Mangel and 

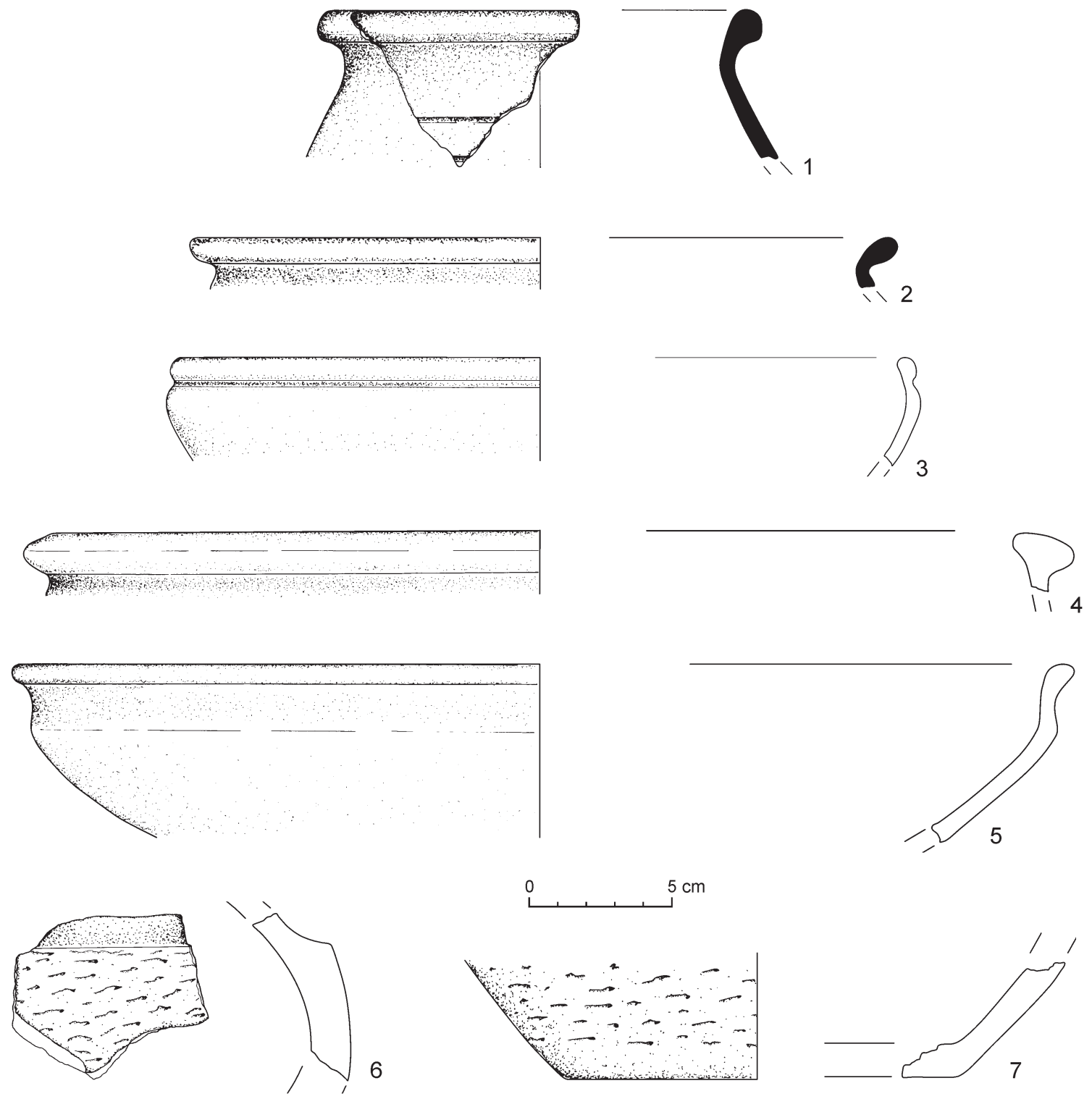

Fig. 3. Mikulovice, Pardubice distr. Typical fragments of pottery from LTB-D1 period. 1 -feature 1/2016b; 2 - feature 252/07; 3, 5 - feature 1942/2009; 4 - feature 175/07; 6 -feature 41/08; 7 - surface finds. Legend: black - fine pottery (drawing T. Jošková).

T. Jošková (2019) brings the latest complete treatment of data on the pool of finds of La Tène components with the manifestations of the burial rite, providing evidence of contacts of the eastern Bohemian region with the Moravian area and other areas of the La Tène settlement in the south-east neighbourhood throughout the periods of La Tène culture from the LTB stage up until the LTD1 stage. It is not surprising that the new excavations, such as in the case of the isolated grave from the LTB2b stage in Mikulovice, provide, as far as possible, additional data on the representatives of the La Tène civilization in the Chrudim-Pardubice region, where other com- mon features with the Moravian region in the grave goods and layouts of graves cannot be overlooked. These include the presence of animal bones in the grave goods, so far known by the first indication in the grave in Chrudim from the LTB1b-c stage (Musil 2008, 52). In this context, the grave in Mikulovice can be seen as another example of a grave unit with elements of grave goods and funeral rite typical of the areas east of Bohemia, the onset of which, according to the example of the grave in Chrudim, with the evidence of meat offerings, can be linked to the process of establishing a local group of La Tène flat cemeteries. 


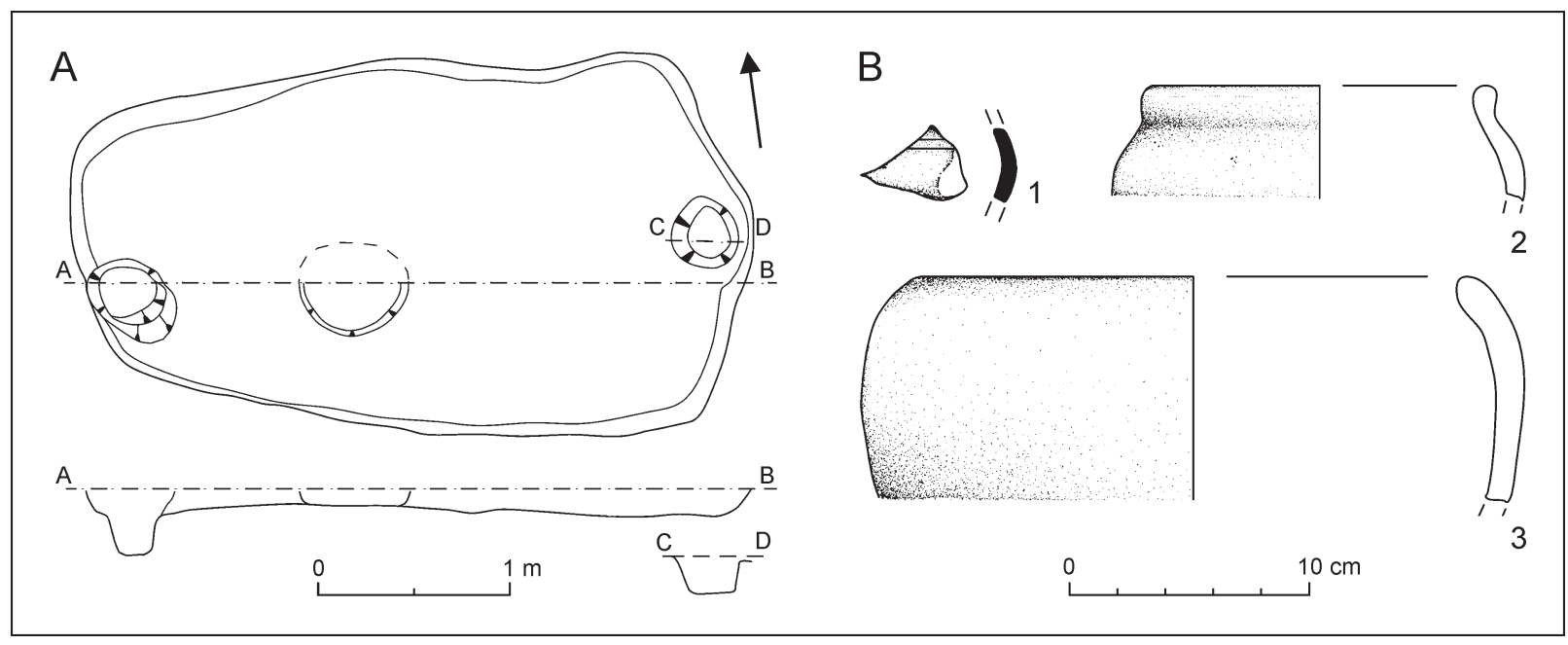

Fig. 4. Mikulovice, Pardubice distr. A - La Tène sunken hut on the parcel no. 26/3; B - pottery finds. Legend: black - fine pottery (drawing and digitization T. Jošková).

\section{EVIDENCE OF THE SETTLEMENT COMPONENT FROM THE LTB-D1 PERIOD}

The question of the chronological and spatial link between the above-mentioned inhumation grave and the prospective settlement may be partially resolved by several relatively recently discovered settlement situations and artefacts. However, for most of the features, which involved La Tène pottery (sherds), dating to the younger part of the Iron Age is not conclusively proven. This is due to the intensive polycultural settlement at the site with frequent intrusions. Only typical fragments of La Tène vessels are shown (Fig. 3; 4: B).

\section{Description and evaluation of archaeological situations}

The clearly La Tène situations include feature 1/2016a from the rescue excavation on parcel no. $26 / 3$ in 2016 (Fig. 1: 7). The shape was trapezoid with oval corners and angled walls, transitioning into a flat bottom. There were three post-holes inside. The feature had an east-west orientation (Fig. 4). The filling contained the total of 13 fragments of pottery, ${ }^{6}$ a stone and a lump of daub.
In formal terms, it is a typical La Tène sunken hut with two opposing posts in the centres of the shorter sides. Here, in the approximate centre of the axis (about $2 / 3$ length), there was an additional, probably support post (Fig. 4: A). Dimensions of feature 1/2016a were not large (max. $346 \times 298 \mathrm{~cm}$, depth $8.3-15 \mathrm{~cm}$ ), however, they are not different from standard dimensions of other sunken huts (cf. Danielisová et al. 2018, 132, fig. 8). With the area of $10.3 \mathrm{~m}^{2}$ it is closer to the lower average (Venclová 2008, 46, 47).

According to the classification by J. Meduna (1980, 54), it is the A-2a type, which is distinguished from the A- 1 type by adding more posts along the approximate axis. Using the classification based on the system defined by J. Waldhauser (1993, 347-380, fig. $12),{ }^{7}$ the feature would fall into group 120 . Analogous types of sunken structures are known from the Bohemian and Moravia. Since this type of construction was used throughout the whole La Tène period (e.g. Radovesice LTA-B: Waldhauser 1993, 347-380; Tuchlovice II LTB2: Šneidrová 1955; Ohrozim LTC2-D1: Čižmář 2015, 439, 440), it is impossible to provide closer chronological determination on this basis (cf. Danielisová et al. 2018, 132, 133, fig. 8). ${ }^{8}$ Apart from a small collection of pottery fragments (29 items in total), no other objects or structural

616 other fragments came from the surface collection at the site of the sunken hut, including a fragment of a belly of turned fine pottery with embellishment (Fig. 4: 1); further, 5 graphite sherds from bodies, 2 fragments of a bowl(?), which can be attached together; 2 fragments of semi-coarse sand pottery; 8 fragments of bellies of micaceous pottery (probably from a single vessel).

7 The partially underground features, 'sunken huts', of the La Tène period are further addressed by K. Motyková-Šneidrová (1960), or more recently in the Bachelor's thesis by J. Hricáková (2007).

8 These types of structures were already present at the end of the Hallstatt period and persisted until the earlier stage of the Egg B2 stage of the Roman period (Hricáková 2007, 25). 
elements were found to aid better specification of the function of the feature. It is standard to assume residential or production purpose for these types of settlement situations (Snajdrová 1955, 199-202; Venclová 2001, 43).

With reservations, it is possible to include feature 1/2016b (Fig. 1: 8) of a circular shape and rounded bottom, found in parcel no. 26/2 (Veselý 2021), to the La Tène period as well. It can be assumed from the absence of culturally different archaeological situations in its surroundings as well as the proximity of the sunken hut $1 / 2016 \mathrm{a}$. It is a larger post hole (diameter $71.5 \mathrm{~cm}$, depth $105.7 \mathrm{~cm}$ ), which was probably part of an unpreserved (or unrecorded) overhead structure. The size of the hole does not differ from typical situations in other settlements of the La Tène time (cf. Venclová 1998, 49-79). Several non-diagnostic pottery fragments were found in the filling, which can be classified as the La Tène or Silesian-Platěnice culture. The only exception is the fragment (Fig. 3: 1) obtained from the bottom layer, which originates from the upper part of a bottle or cup made of fine material, turned on the wheel, with embellishment.

Dating of the other settlement situations in Mikulovice to the La Tène period is uncertain due to the number of other, culturally different finds in the filling. It is a storage pit, feature 175/2007, in the 'Pod Kostelem' location (Fig. 1: 1) with a relatively regular circular shape and slightly curved walls. A fragment of ledged rim edge was found in the filling (Fig. 3: 4); in addition, there were fragments dating to the Unětice culture, as well as HAB-D1 and HD2-LTA. In the same location (Fig. 1: 2), there was a pit with an irregular layout - feature 252/2008. In addition to the share of fragments from HD2-LTA and from the Urnfield culture period, there was also a fragment of a bowl or goblet from fine pottery (Fig. 3: 2).

Other finds were excavated at the 'V Loučkách' site. A fragment of a bipartite pots with grated surface (Fig. 3: 6) comes from a simple, oval-shaped hole (feature 41/2008; Fig. 1: 3). In addition, fragments of vessels dating to the Urnfield culture were found in the filling. A regular round object, feature 1942/2009 (diam. $110 \mathrm{~cm}$, preserved depth max. $69.5 \mathrm{~cm}$; Fig. 1: 4) was situated in the vicinity of the La Tène grave 2094. Based on the slightly curved walls passing into an almost flat bottom, it can be interpreted as a storage pit. The filling was rather mixed and contained pottery of the Unětice culture, Urnfield culture, HD2-LTA and the Roman period, as well as a few fragments of burned La Tène bowls (Fig. $3: 3,5)$.

\section{Analysis of pottery fragments}

Apart from the numerous finds from LTA (Jošková 2020, 130-131), chronologically the oldest pottery finds are the fragments of bowls from feature 1942/2009 (Fig. 1: 3). In both cases, they are slightly burned bowls of fine sand pottery. One of them has a slightly curved profile (Fig. 3: 5); another one has fluting under its lip (Fig. 3:3). Based on the analogies from other cemeteries (Kloboučky, Vyškov district; Čižmárová 2013, pl. 21: 12,13) as well as settlements, these can be dated to LTB, or LTB2-C1 (Salač/Kubálek 2015, 54, fig. 24; Venclová 1998, 158). The bowl fragment, with fluting under the lip finds its closest analogy in the burial grounds in Hořenice, Náchod district, to be generally dated to LTB2 (Mangel 2009, 39, pl. 20: 2).

The goblet/bottle fragment of fine pottery with a thickened rim (Fig. 3: 1) ${ }^{9}$ from feature 1/2016b could also be dated to LTB2-C1/2 due to its embellishment with engraved lines and the profile of the lip. Similar shapes are known from cemetery (e.g. Vliněves; Limburský et al. 2015, fig. 11: 3). Only very few fragments were found in the filling of the sunken hut 1/2016a. Their fractional nature and the absence of other chronologically diagnostic artefacts make more accurate dating impossible. Both in the case of a neckless bowl with rounded profile (Fig. 4:3), and the fragment of wheel turned fine pottery with an incised line (Fig. 4: 1) can be placed within a wide range of the LTB-D1 stages. The same applies to the fragment of a S-profiledpot with curved neck with a slightly curved neck (Fig. 4: 2), although these variants are most often dated to LTB-C1 (Venclová 2001, 49; Venclová et al. 2008, 192).

A fragment of the ledged rim can be considered chronologically younger (Fig. 3: 4), found in the storage pit in the 'Pod Kostelem' site (Fig. 1: 1). These types of rims are generally associated with the oppidum of the LTC2-D1 stages and they are known directly from the oppida (Danielisová 2010,99, 104) or lowland settlements (Wilczek 2014, pl. 7: 12; 13: 11) as well as the rectangular enclosures (Jošková 2016, 107, 123). We can apply the same dating to the bipartite pots with grated surface from feature 41/08 (Fig. 1: 3; 3: 6) and from the surface collection in 2010 (Fig. 1: 6; 3: 7). ${ }^{10}$ This type of surface treatment is most often associated with LTC2-D1, with the beginnings on LTC1 (Venclová 1998, 160; 2001, 30-32).

\footnotetext{
9 Due to the small size, it is not possible to establish clearly whether it is a goblet or a bottle (bottle: diam. of the neck $\leq$ max. 1/2 diam. of the belly; cup: max. diam. is equal or slightly exceeds the diam. of the mouth; according to Venclová 1998, 84, 85).

${ }^{10}$ In the collection (apart from BB, BC-HD1 and HD2-LTA sherds), there were four other small fragments of bellies of fine sand pottery, with polished finish and sandwich firing effect, which can be dated to LTB-D1 by their nature.
} 
The presented data confirm the existence of settlement activities in Mikulovice during the period LTB-C1. It is also evidenced by the nature of individual fragments, which can be placed directly into LTB2-C1 (Fig. 3: 1, 3, 5; 4: 2), or to a wide range LTB-D1 (Fig. 4: 1, 3). The presence of the settlement pottery from the respective period is important to complement the hitherto not well documented part of La Tène period in the Chrudim-Pardubice region (see Thér/Mangel/Gregor 2015). Due to the presence of a few fragments typical of LTC2-D1, we may assume that the activities could continue even during the younger stages of La Tène period.

The question of spatial relations with the La Tène grave 2094 has not yet been reliably resolved. The nearest demonstrably La Tène settlement feature - sunken hut (1/2016a) is located more than $600 \mathrm{~m}$ away. While some of the findings indicate the possibility of even closer settlement situations, the data do not yet provide a more accurate determination of the chronological-spatial links.

\section{CONCLUSION}

About 15 years ago, Mikulovice in the Pardubice district was known mainly for its rich cemetery from the Early Bronze Age, as a large settlement from the period HD2-LTA (Fig. 1), or for its Roman period activities. Subsequent settlements in the later periods of La Tène period were not documented here. In 2009, a male inhumation grave was excavated, whose affiliation to the Late Iron Age was undeniable. Based on the nature of the equipment it can be dated to the LTB2b stage. The context of placing of the deceased and the isolated location of the grave are also interesting. A coffin with a cover and a step projection were recorded (Fig. 2). Together with the iron ring with knobs (Fig. 2: 3), we may assume links with the south-eastern regions.

The chronological and spatial relationship with the pottery finds, identified at the site in the following years, is unclear. Typical pottery fragments are few, but the condition may be due to the poor detectability of the LTB-C1 pottery to some extent. The settlement features are mainly represented by the sunken hut (feature 1/2016a) at the southern edge of the village (Fig. 1: 7, 8; 4) and the nearby post hole (feature $1 / 2016 b$ ). Due to the presence of items of other cultures in the filling, the emergence and use of several other settlement features containing pottery from LTB-D1 cannot be clearly related to the Late Iron Age. Based on the analysis of the ceramic material, the settlement activities of the site can be already assumed in LTB2-C1. A few fragments indicate the possibility of activities in the LTC2-D1 period.

In contrast to the Mikulovice settlement during the HD2-LTA period (Fig. 1), the La Tène (LTB-D1) finds appear sporadic. However, based on the above data, it must be taken into account in the future. The southern edge of the village (Fig. 1: 7, 8) is interesting, as the ongoing settlement can be expected here. The findings are important to complement the picture of the Pardubice-Chrudim settlement region, especially during the LTB-C1 period, which is still not well known.

\section{BIBLIOGRAPHY}

Bujna 2003 - J. Bujna: Spony z keltských hrobov bez výzbroje z územia Slovenska. (Typovo-chronologické triedenie LTB- a C1-spôn.) Slovenská archeológia 51, 2003, 39-108.

Bujna 2005 - J. Bujna: Kruhový šperk z laténskych ženských hrobov na Slovensku. Nitra 2005.

Čižmář 1978 - M. Čižmář: Keltské pohřebiště v Makotřasích, okres Kladno. Památky archeologické 69, 1978, 117-144.

Čižmář 2015 - I. Čižmář: Pozdně laténská chata z Ohrozimi, okr. Prostějov. Archeologické rozhledy 67, 2015, 438-463.

Čižmářrová 2009 - J. Čižmářová: Keltská pohřebiště z Holubic a Křnovic. Pravěk. Supplementum 19. Brno 2009.

Čižmářová 2011 - J. Čižmářová: Keltská pohřebiště na Moravě. Okresy Brno-město a Brno-venkov. Brno 2011.

Čižmářrová 2013 - J. Čižmářová: Keltská pohřebiště na Moravě. Okresy Blansko a Vyškov. Brno 2013.

Čižmářová 2017 - J. Čižmářová: Keltská pohřebišsě na Moravě. Okresy Hodonin, Kroměřž, Olomouc, Opava, Prostějov, Přerov, Uherské Hradiště a Zlín. Brno 2017.

Čižmářová 2019 - J. Čižmářová: Keltská pohřebiště na Moravě. Okresy Břeclav a Znojmo. Brno 2019.
Danielisová 2010 - A. Danielisová: Oppidum České Lhotice a jeho sídelnízázemí. Archeologické studijní materiály 17. Praha 2010.

Danielisová et al. 2018 - A. Danielisová/J. Kysela/T. Mangel/R. Kyselý/J. Militký: Iron Age site in Žehuň, Central Bohemia. An open settlement with central functions. Památky archeologické 109, 2018, 127-178.

Demek/Mackovčin 2006 - J. Demek/P. Mackovčin (eds.): Hory a nižiny. Zeměpisný lexikon ČR. Brno 2006.

Dreslerová et al. 2019 - D. Dreslerová/R. Kozáková/M. Metlička/V. Brychová/P. Bobek/ Č. Čišecký/A. Pokorná/ J. Michálek/B. Strouhalová: Human activity in the upper regions of the Šumava mountains during prehistory as reflected in archaeological and proxy data. Multidisciplinary research of the La Tène archaeological site in the Sklářské valley. Fines Transire 28, 2019, 187-199.

Ernée/Langová 2020 - M. Ernée/M. Langová (eds.): Mikulovice. Pohřebiště starši doby bronzové na Jantarové stezce. Památky archeologické. Supplementum 21. Praha 2020. 
Frolík/Sedláček/Švédová 2010 - J. Frolík/R. Sedláček/J. Švédová: Pokračování záchranného archeologického výzkumu v Mikulovicích (okr. Pradubice) v roce 2009. Zprávy České archeologické společnosti. Supplément 78, 2010, 13, 14.

Hlava/Frolík 2020 - M. Hlava/J. Frolík: Z historie archeologického poznání. In: Jošková/Langová/Jílek 2020, 24-51.

Holodňák 1988 - P. Holodňák: Keltská pohřebiště ve středním Poohří. Památky archeologické 79, 1988, 38-105.

Hricáková 2007 - J. Hricáková: Laténské polozemnice v Čechách. Bakalářská práce. Ústav pro pravěk a ranou dobu dějinnou. Filozofická fakulta. Univerzita Karlova v Praze. Praha 2007. Online availabe on: http://hdl.handle.net/ 20.500.11956/13173

Jančák/Hrnčiarová/Mackovčin 2009 - V. Jančák/T. Hrnčiarová/P. Mackovčin: Geografická poloha. In: T. Hrnčiarová/P. Mackovčin/I. Zvara: Atlas krajiny České republiky. Praha 2009, 54-72.

Jošková 2016 - T. Jošková: Valový objekt u Markvartic (okr. Jičín) ve světle analýz a archeologických poznatků. Diplomová práce. Katedra archeologie. Filozofická fakulta. Univerzita v Hradci Králové. Hradec Králové 2016. Online availabe on: https://theses.cz/id/spqjf2/STAG85498.pdf

Jošková 2020 - T. Jošková: Když udeřilo železo... In: Joškovál LangoválJílek 2020, 112-131.

Jošková/Langová/Jílek 2020 - T. Jošková/M. Langová/J. Jílek (eds.): Mikulovice. Život na hraně. Pardubice 2020.

Klementová/Sankot 2020 - J. Klementová/P. Sankot: Neue latènezeitliche Gräber in Hostivice, Landkreis PragWest. In: I. Čižmář/H. Čižmářová/A. Humpolová (eds.): Jantarová stezka v proměnách času. Brno 2020, 245-257.

Limburský et al. 2015 - P. Limburský/P. Sankot/H. Březinová/J. Likovský: Laténské pohřebiště v pískovnách u Vliněvsi, okr. Mělník. Památky archeologické 106, 2015, $181-246$.

Lorenz 1978 - H. Lorenz: Totenbrauchtum und Tracht. Untersuchungen zur regionalen Gliederung in der frühen Latènezeit. Bericht der Römisch-Germanischen Kommission 59, 1978, 1-380.

Mangel 2009 - T. Mangel: Laténská pohřebiště v horním Polabí. Hradec Králové 2009.

Mangel/Danielisová/Jílek 2013 - T. Mangel/A. Danielisová/ J. Jílek: Keltové ve východních Čechách. Hradec Králové Nasavrky - Pardubice 2013.

Mangel/Jošková 2019 - T. Mangel/T. Jošková: East Bohemian Finds of Belt Segments with a Central Knob and Sites Plates as Evidence of Interregional Contacts during the La Tène period. In: N. Beljak Pažinová/D. Repka (red.): Sedem kruhov Jozefa Bujnu. Studia Historica Nitriensia 23. Supplementum 2. Nitra 2019, 465-480.

DOI: https://doi.org/10.17846/SHN.2019.23.S.465-480

Mangel/Zavoral 2017 - T. Mangel/T. Zavoral: Doklad laténského pohřbu z Duban, okr. Pardubice. Archeologie ve středních Čechách 21, 2017, 323-329.

Meduna 1980 - J. Meduna: Die laténezeitlichen Siedlungen in Mähren. Praha 1980.

Motyková-Šneidrová 1960 - K. Motyková-Šneidrová: Osídlení z mladší doby laténské, z doby římské a stěhování národů v Záluží u Čelákovic II. Památky archeologické 51, 1960, 161-183.

Musil 2008 - J. Musil: Nález laténského hrobu v Chrudimi v ulici Obce Ležáků. Časopis společnosti prátel starožitností 116, 2008, 50-54.
Pecinovská/Baloun/Sankot 2014 - M. Pecinovská/L. Baloun/ P. Sankot: Laténské pohřebiště v Bašti, okr. Praha-východ. Archeologie ve středních Čechách 18, 2014, 745-766.

Salač/Kubálek 2015 - V. Salač/T. Kubálek: Laténská sídlištní keramika v severozápadních Čechách. Praha 2015.

Sankot 1991 - P. Sankot: Motifs zoomorphes dans l'art laténien de la Bohème au III ${ }^{\text {e }}$ siècle avant J.-C. In: Etudes Celtiques 28, 1991, 401-433.

DOI: https://doi.org/10.3406/ecelt.1991.1970

Sedláček 2007 - R. Sedláček: Archeologický výzkum při výstavbě kolonie RD v Mikulovicích. Zprávy České archeologické společnosti. Supplément 68, 2007, 28.

Sedláček et al. 2009 - R. Sedláček/J. Frolík/J. Musil/J. Švédová: Nejnovější výzkumy na polykulturní lokalitě Mikulovice, okr. Pardubice. Zprávy České archeologické společnosti. Supplément 75, 2009, 19, 20.

Sedláček/Sankot 2013 - R. Sedláček/P. Sankot: Découverte d'une fibule à masque dans la structure no 8 de Mikulovice, district dePardubice, Bohême del'Est.In:S. Krausz/ A. Colin/K. Gruel/I. Ralston/T. Dechezleprêtre (dir.): L'Âge du Fer en Europe. Mélanges offerts à Olivier Buchsenschutz. Ausonius éditions. Mémoires 32. Bordeaux 2013, 567-581.

Sedláček/Švédová 2011 - R. Sedláček/J. Švédová: Sezóna 2010 v Mikulovicích (okr. Pardubice). Zprávy České archeologické společnosti. Supplément 81, 2011, 11, 12.

Sedláčková/Waldhauser 1987 -H. Sedláčková/J. Waldhauser: Laténská pohřebiště ve středním Polabí, okr. Nymburk. Památky archeologické 78, 1987, 134-204.

Šneidrová 1955 - K. Śneidrová: Laténská osada u Tuchlovic na Novostrašecku. Památky archeologické 46, 1955, 185-206.

Stránská 2016 - P. Stránská: Antropologický posudek č. 1151. Lokalita Mikulovice, okr. Pardubice. Archiv AÚ AV ČR, č. P7A 43204. Praha 2016. Unpublished.

Thér/Mangel/Gregor 2015 - R. Thér/T. Mangel/M. Gregor: Život hrnčíre začíná v LT A... Výroba keramiky v době laténské na Chrudimsku. Červený Kostelec 2015.

Venclová 1998 - N. Venclová: Mšecké Žehrovice in Bohemia. Archaeological Beckground to a Celtic Hero $3^{\text {rd }}-2^{\text {nd }}$ Cent. B.C. Sceaux 1998.

Venclová 2001 - N. Venclová: Výroba a sídla v době laténské. Projekt Loděnice. Praha 2001.

Venclová 2008 - N. Venclová (ed.): Archeologie pravěkých Čech 7. Doba laténská. Praha 2008.

Venclová et al. 2008 - N. Venclová/V. Čulíková/D. Dreslerová/M. Gregorová/M. Hložek/L. Kovačiková/R. Kyselý/ M. Malkovský/Fr. Marek/L. Peške/J. Zavřel: Hutnický region Řícansko. Praha 2008.

Veselý 2021 - J. Veselý: Stručná nálezová zpráva ze záchranného archeologického výzkumu v Mikulovicích na parc.č. 26/2 RD Koppová. Nálezová zpráva č. j. VČM 402/2016. Archiv Východočeského muzea v Pardubicích. Pardubice 2021. Unpublished.

Vokolek 1993 - V. Vokolek: Počátky osídlení východních Čech. Hradec Králové 1993.

Waldhauser 1978 II - J. Waldhauser (ed.): Das keltische Gräberfeld bei Jenišũv Újezd in Böhmen. I. Band - Quellen und Gutachten. II. Band - Auswertung. Archeologický výzkum v severních Čechách 6-7. Teplice 1978.

Waldhauser 1979 - J. Waldhauser: Konfrontation der anthropologischen und archäologischen Ermittlung von Männer-, Frauen- und Kindergräbern auf keltischen Nekropolen in Böhmen. Anthropologie 17, 1979, 55-62. 
Waldhauser 1987 - J. Waldhauser: Keltische Gräberfelder in Böhmen. Bericht der Römisch-Germanischen Kommission 68, 1987, 25-179.

Waldhauser 1988 - J. Waldhauser: Keltská pohřebiště na Jičínsku. Zpravodaj Krajského muzea východních Čech 15, 1988, 56-76.

Waldhauser 1993 - J. Waldhauser et. al.: Die hallstatt- und laténzeitliche Siedlung mit Gräberfeld bei Radovesice in

Manuscript accepted 6. 6. 2021

Translated by Martin Brňovják

Mgr. Tereza Jošková

Univerzita Hradec Králové

Rokitanského 62

CZ - 50003 Hradec Králové

tereza.joskova@uhk.cz

PhDr. Pavel Sankot

Národní muzeum

Václavské náměstí 68

CZ - 11579 Praha

pavel.sankot@nm.cz
Böhmen. Archeologický výzkum v severních Čechách 21. Praha 1993.

Wilczek 2014 - J. Wilczek: Hrnčířské dílny ve Višňovém. Pravěk. Nová řada 22, 2014, 167-256.

Zavoral 2015 - T. Zavoral: Záchranný archeologický výzkum Mikulovice "Východ". Inženýrské sitě a komunikace pro RD. Nálezová zpráva. Pardubice 2015. Archiv Východočeského muzea v Pardubicích, VČM 521/2014. Unpublished.

PhDr. Vít Vokolek

Jindřišská 1757

CZ - 53002 Pardubice 
